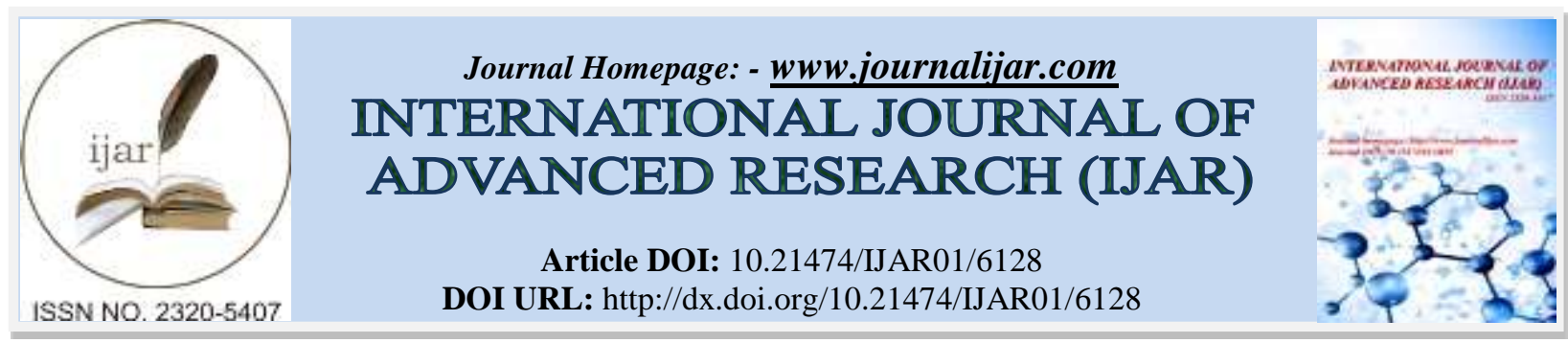

RESEARCH ARTICLE

\title{
PHYSICO-CHEMICAL ANALYSIS OF COASTAL SOIL SAMPLES IN THE WEST COAST OF KANYAKUMARI DISTRICT, TAMILNADU.
}

\section{S. S. Sajitha ${ }^{1}$, P. Metilda ${ }^{2}$ and G. Aldous Jenin ${ }^{3}$.}

1. Department of Chemistry, Annai Velankanni College,Tholayavattam.Kanyakumari district,Tamilnadu,India.

2. Department of Chemistry, Nesamony Memorial Christian College,Marthandam.Kanyakumari district,Tamilnadu,India.

3. Department of Bio-Chemistry, Lekshmipuram college of arts and science,Neyyoor Kanyakumari district,Tamilnadu,India.

\section{Manuscript Info}

-........................

Manuscript History

Received: 21 October 2017

Final Accepted: 23 November 2017

Published: December 2017

Keywords:-

Organic Matter (O.M), Atomic Absorption Spectroscopy (Aas).

\section{Abstract}

Environmental pollution is an undesirable change in physical chemical characteristics of air, soil and water. Now a day all the pollutants are accumulated in coastal regions. Coastal soil contamination also occurs due to spill of effluents by industries. The present survey was made to study of the some physico-chemical parameters of soil at ten different places of kanyakumari district coastal region. This study carried out using field determination of texture and low cost electrochemical approach was used for $\mathrm{pH}$, and electrical conductivity. The soil properties like organic matter, macro nutrients $(\mathrm{N}, \mathrm{P}, \mathrm{K})$ and micro nutrients $(\mathrm{Zn}, \mathrm{Cu}, \mathrm{Mn}, \mathrm{Fe})$ are determined by Atomic absorption spectroscopy. The results showed that soils in the coastal region are made up of sandy and silt, soil $\mathrm{pH}$ range from (7.6 to8.2) which are alkaline. Electrical conductivity of soil solution increased with increasing concentration of ions. Electrical conductivity range from (0.76 to $2.0 \mathrm{~d} \mathrm{~S} \mathrm{m-1).} \mathrm{Available} \mathrm{nitrogen} \mathrm{range} \mathrm{from} \mathrm{(7.0to} 41 \mathrm{ppm})$, phosphorus range from (41.3 to $50 \mathrm{ppm}$ ) and potassium range from (29 to $46 \mathrm{ppm})$. The micro nutrients such as zinc ( 0.30 to $0.70 \mathrm{ppm})$, copper (0.06 to $10.28 \mathrm{ppm})$, iron (0.21 to $2.38 \mathrm{ppm})$ and manganese (1.27 to $3.62 \mathrm{ppm})$ have variation in comparison to different areas.

Copy Right, IJAR, 2017,. All rights reserved.

\section{Introduction:-}

Soil is a component of the terrestrial ecosystem fulfils many function including that are essential for sustaining plant growth (Nwachokar et al.,2009). The change in physico chemical properties of soil leads to infertile or barren soil that does not support normal growth of vegetation for years (Jha et al.,1991). The climate and other factor largely affect the soil formation. Soil is not a dead inert matter of minerals. The mineral composition of soil, the organic matter within it and the environment, all are determined by the chemical properties of soil (Joffe et al.,1949). Understanding of soil chemical reaction and processes is essential for developing innovative resource management strategies, and understanding and regulating the behavior of the terrestrial ecosystem at regional and global scale (Schnitzer et al., 1986). Physico chemical characteristics of different soils vary in space and time due to variation in topography, climate, physical weathering processes, vegetation cover, microbial activities, and several other biotic 
and a biotic variables (Paudel et al., 2003). The industrialization and development in agriculture are necessary to meet the basic requirement of people, at the same time it is necessary to preserve the environment (Joshi et al., 2011). $\mathrm{pH}$ is a most important physical properties of soil. It having great effects on solute concentration and absorption in soil (Akpoveta et al.,2010). At low $\mathrm{pH}$ values solubility of micronutrients is high while at high $\mathrm{pH}$ solubility and availability of micronutrient to plant is declined (Brady et al.,2002). Variability in soil texture can directly or indirectly influence many other soil functions and soil threats such as soil erosion (Adhikari et al.,2009). A rise in temperature of soil accelerates chemical reaction, reduces solubility of gases and decrease $\mathrm{pH}$ of soil (Shirbhate et al.,2012). Soluble salt concentration in soil and is commonly used as a measure of salinity (Wagh et al.,2013) Nitrogen cycle plays an important role in soil system and is influenced by biological processes. It is required for growth of plant and is a constituent of chlorophyll, plant protein and nucleic acid (Jain et al.,2014). Soil nitrogen is also directly related with soil organic carbon (Singh et al.,2013 Supply of nitrogen either through organic and inorganic sources also plays an important role for higher winter sorghum productivity in addition to the moisture conservation (Patil et al.,2005). phosphorus content of the soil was higher in topographic position as compared to soils occurring on lower topographic position (Singh et al.,2013). The soil with high organic matter content have better supplies of organic phosphate for plant uptake than have the soils with low organic content (Miller et al 2001). The soil with minimum leaching are known to contain high amount of phosphorus as compared to the soil with maximum leaching (Ahraf et al.,2012).Potassium is not an integral part of any major plant component but it plays a key role in a vast array of physiological process vital to plant growth from protein synthesis to maintenance of plant water balance (Sumithra et al., 2013). Potassium fixation occurs when soil dry and the potassium is bonded between layers of clay (Wagh et al., 2013). It decreases with an increase in depth of soil (Campbell et al., 1961). Soil organic matter is an important property of soil. If the soil is poor in organic matter then it enhances the process of soil erosion. The presence of higher content of organic matter in the soil can be another reason for lowering of the $\mathrm{pH}$ (Hodes et al., 1996). Soil organic matter content has decreased from surface to subsoil due to levelling (Helburg et al., 1978). The decomposition rate of organic matter has a tendency to increase as weather warm and to furnish maximum plant growth conditions (Russell, 1950). Organic matter commonly increases water content at field capacity, increases available water content in sandy soil and increases both air and water flows rates through fine textured soil (Ramulu et al.,2001).

\section{Materials and methods:-}

\section{Study Area:-}

The study area chosen for the present work is kanyakumari district coastal region. Which is covering a distance of 65 $\mathrm{Km}$ from Vattakottai to Vallavilai of Tamilnadu coast region. It is shown in Fig.1.Numerous industries, chemical factories and aquaculture farms are also developing along these coastal regions, it makes much attention for present and future research.

\section{Soil collection and preparation:-}

The study was conducted at ten different coastal regions of kanyakumari district. Coastal soil sample were collected using Peterson grab at all the designated location during low tide. The samples collected sites under study were labelled as S1, S2, S3, S4, S5, S6, S7, S8, S9 and S10. The distance between each site falls around $6 \mathrm{Kms}$. the collected soil samples stored in polythene bags immediately; after the soil was withdrawn the colour and texture were identified. The soils were air dried, crushed using pestle and mortar and then passed through a $10 \mathrm{mesh}$ (2mm) screen before analysis. The soil analysis was completed within two months after collection

\section{Physico-chemical Analysis:-}

\section{Determination of $\mathbf{p H}$, electrical conductivity and organic matter:-}

$\mathrm{P}^{\mathrm{H}}$ was determined in (1:2 ratio) $40 \mathrm{~g}$ soil+ $80 \mathrm{ml}$ water suspension using an ELICO pH meter (Graham 1959). Electrical conductivity was determined using a Systronics conductivity meter. Total organic matter estimated by Walkley and Black method.

\section{Estimation of Micronutrients $(\mathbf{N}, \mathbf{P}, \mathbf{K})$ :-}

Macronutrients like nitrogen estimated by Kjeldahl method. Available phosphorus estimated by Olsen's colorimetric method. Potassium analyzed by atomic absorption spectrometer (IL-257).

\section{Estimation of Micronutrients (Fe, Mn, $\mathrm{Zn} \& \mathrm{Cu}$ ):-}

Elemental analysis the soil samples are decomposed into soluble forms by acid digestion and it is estimated by atomic absorption spectroscopy (IL-257) 
Graphical representations of physico chemical characteristics of various coastal area samples of kanyakumari district.
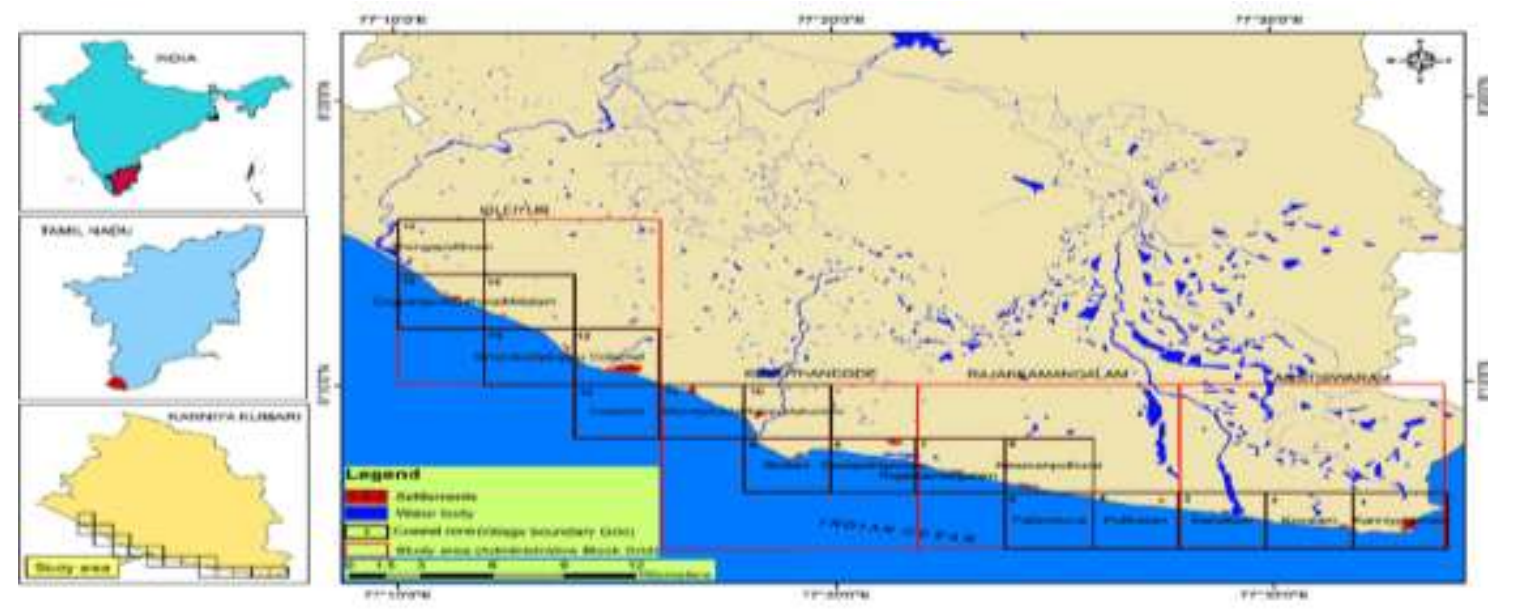

\begin{tabular}{|c|c|}
\hline SAMPLE SITE NUMBERS & LOCATION \\
\hline S1 & Vattakottai \\
\hline S2 & Chotthavilai \\
\hline S3 & Rajakkamangalam \\
\hline S4 & Muttam \\
\hline S5 & Manavalakurichi \\
\hline S6 & Kottilpaadu \\
\hline S7 & Kurumpanai \\
\hline S8 & Pattanam \\
\hline S9 & Thoothoor \\
\hline S10 & Vallavilai \\
\hline
\end{tabular}

Fig.1:- Study area location. 


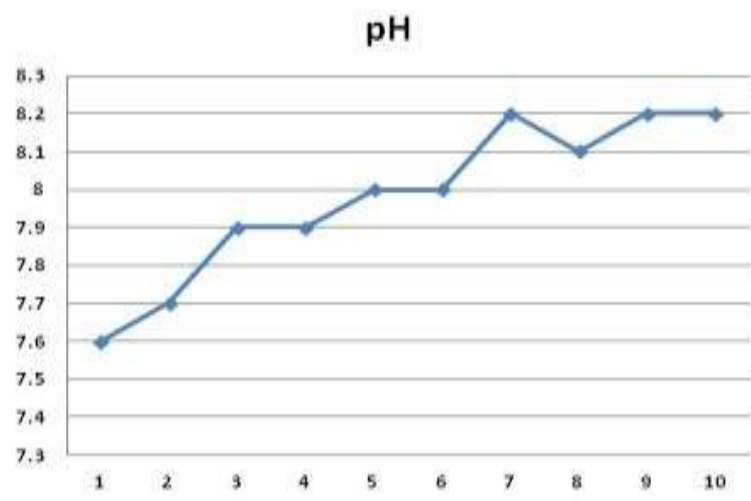

O.M

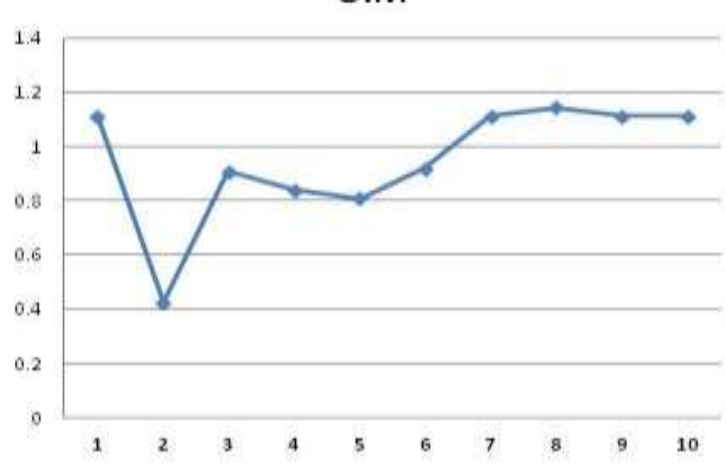

E.C

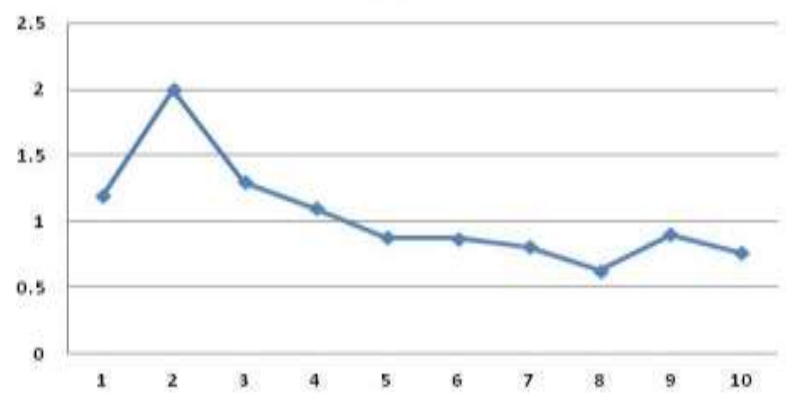

$\mathrm{N}$

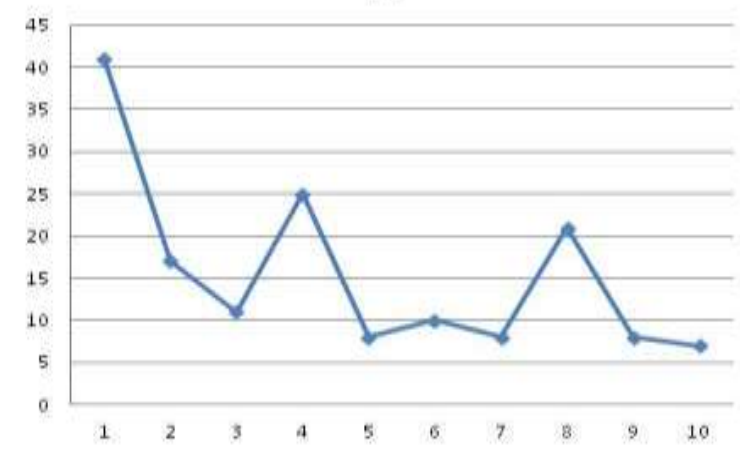

Fig .2:- PHYSICOCHEMICAL PARAMETES ( ${ }^{\mathrm{H}}$,E.C,O.M,N) OF COASTAL SOIL SAMPLES X-axis: Soil Samples (S1-S10) Y-axis: Physico-Chemical Characters
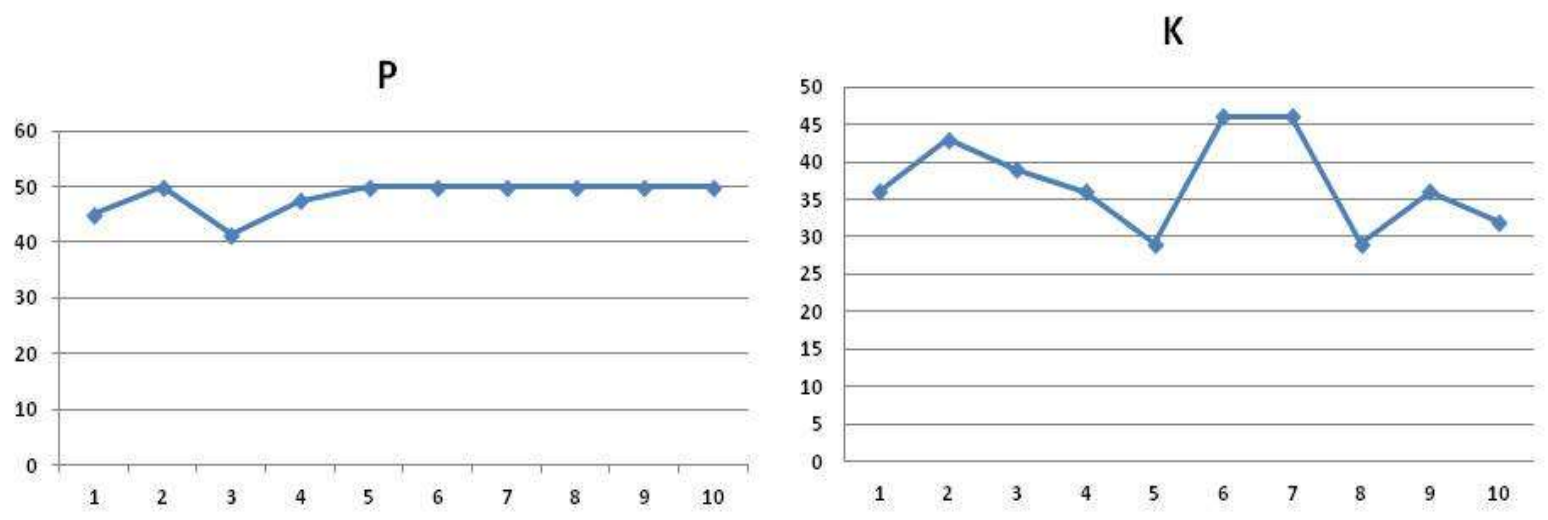
$\mathrm{Cu}$

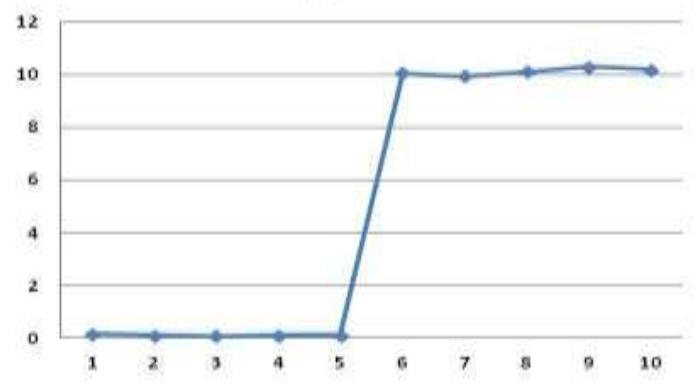

Fe

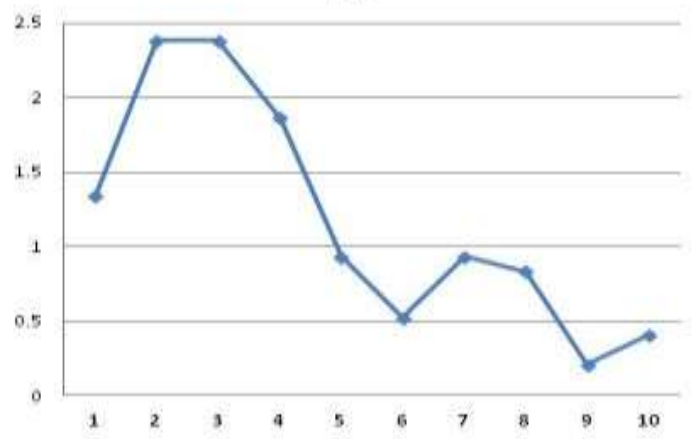

$\mathrm{Zn}$

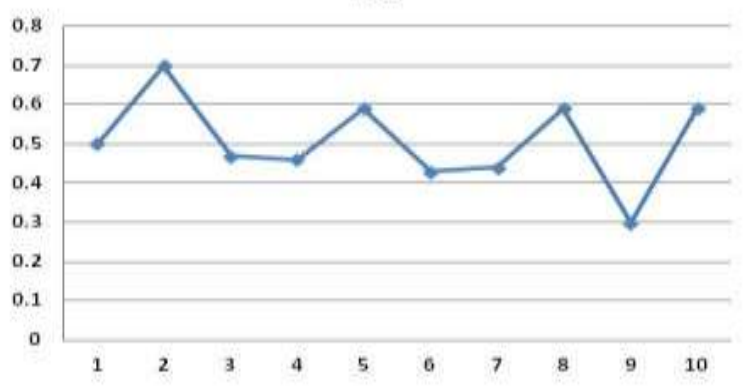

Fig .3:- PHYSICOCHEMICAL PARAMETES (P,K,Cu,Zn,Fe,Mn) OF COASTAL SOIL SAMPLE X-axis: Soil Samples(S1-S10) Y-axis: Physico-Chemical Characters

\section{Results and Discussion:-}

The physico- chemical properties of ten different coastal regions of Kanyakumari district is shown in Table 1. Samples site numbers and locations are given below. $\mathrm{pH}$ and electrical conductivity of different coastal regions show that $\mathrm{pH}$ variation is very less but conductivity is more in Chotthavilai region (S2), in comparison to other nine places very less electrical conductivity in Pattanam (S8). The presence of higher content of organic matter in the soil can be another possible reason for lowering the pH.The organic matter value ranges from 0.4247 to 1.3254 .

Nitrogen cycle place an important role in soil system and is influenced by biological process. The results in ten different regions showed least amount of nitrogen in all regions. Phosphorus helps the transformation of solar energy into chemical energy. Among all the samples the least amount of Phosphorus recorded in Rajakkamangalam(S3). Potassium is not an integral part, but it plays a key role in vast array of physiological process like maintaining the plant water balance. The lowest value of potassium recorded in Manavalakurichi and Pattanam(S5\& S8). The highest value of potassium in regions Kottilpaadu and Kurumpanai(S6 \& S7).Graphical representation of physicochemical parameters in Fig.2. and Fig.3. respectively.

Micronutrients analysis was done in Zinc,Iron ,Copper and Manganese, results showed that Zinc is not an adequate amount in all the regions, it is particularly common in high $\mathrm{pH}$ soils. Iron is essential for chlorophyll synthesis, iron deficiency results in regions S5-S10, when compared with regions S1-S4. Copper is a component of some enzymes, copper deficiency results in regions S1-S5, when compared with regions S6-S10 the availability of copper is in significant amount. The availability of manganese is in significant amount in all regions. Compared with all the regions Vattakottai has enriched amount of manganese.

\begin{tabular}{|c|c|c|c|c|c|c|c|c|c|c|}
\hline Site No & $\mathbf{p H}$ & $\begin{array}{c}\mathbf{E . C} \\
(\mathbf{d ~ s m} \\
\mathbf{1})\end{array}$ & $\begin{array}{c}\mathbf{O} \cdot \mathbf{M} \\
\mathrm{Kg} \mathrm{ha}^{-1}\end{array}$ & $\begin{array}{c}\mathbf{N} \\
(\mathrm{ppm})\end{array}$ & $\begin{array}{c}\mathbf{P} \\
(\mathrm{ppm})\end{array}$ & $\begin{array}{c}\mathbf{K} \\
(\mathrm{ppm})\end{array}$ & $\begin{array}{c}\mathbf{C u} \\
(\mathrm{ppm})\end{array}$ & $\begin{array}{c}\mathbf{Z n} \\
(\mathrm{ppm})\end{array}$ & $\begin{array}{c}\mathbf{F e} \\
(\mathrm{ppm})\end{array}$ & $\begin{array}{c}\mathbf{M n} \\
(\mathrm{ppm})\end{array}$ \\
\hline S1 & 7.6 & 1.20 & 1.1129 & 41 & 45 & 36 & 0.16 & 0.50 & 1.34 & 3.62 \\
\hline
\end{tabular}




\begin{tabular}{|c|c|c|c|c|c|c|c|c|c|c|}
\hline S2 & 7.7 & 2.0 & 0.4247 & 17 & 50 & 43 & 0.11 & 0.70 & 2.38 & 1.46 \\
\hline S3 & 7.9 & 1.30 & 0.9065 & 11 & 41.3 & 39 & 0.06 & 0.47 & 2.38 & 1.78 \\
\hline S4 & 7.9 & 1.10 & 0.8398 & 25 & 47.4 & 36 & 0.09 & 0.46 & 1.86 & 1.90 \\
\hline S5 & 8.0 & 0.88 & 0.8094 & 8.0 & 50 & 29 & 0.09 & 0.59 & 0.93 & 1.52 \\
\hline S6 & 8.0 & 0.87 & 0.9187 & 10 & 50 & 46 & 10.04 & 0.43 & 0.52 & 1.37 \\
\hline S7 & 8.2 & 0.81 & 1.1129 & 8.0 & 50 & 46 & 9.94 & 0.44 & 0.93 & 1.37 \\
\hline S8 & 8.1 & 0.63 & 1.1433 & 21 & 50 & 29 & 10.11 & 0.59 & 0.83 & 1.65 \\
\hline S9 & 8.2 & 0.90 & 1.1129 & 8.0 & 50 & 36 & 10.28 & 0.30 & 0.21 & 1.27 \\
\hline S10 & 8.2 & 0.76 & 1.1129 & 7.0 & 50 & 32 & 10.18 & 0.59 & 0.41 & 1.44 \\
\hline
\end{tabular}

Table 1:- Physico chemical parameters of coastal soil samples of kanyakumari District

\section{Conclusion:-}

Coastal regions in Kanyakumari district is polluted by industrial wastes and non biodegradable pollutants. Understanding of coastal soil physico chemical parameters are essential for developing innovative resource management strategies and regulating the behavior of terrestrial eco system at regional and global scale. Among the ten different coastal region of Kanyakumari district, Vattakottai and Chotthavilai have adequate amount of phosphorous, potassium, iron and manganese. All the macro and micronutrients are very less in Manavalakurichi ,Pattanam and Kottilpaadu, these regions show high salinity. Thoothoor coastal region has very weak concentration of micronutrients $(\mathrm{Zn}=0.30, \mathrm{Fe}=0.21, \mathrm{Mn} 1.25 \mathrm{ppm})$. In Chothavilai, Muttam and Manavalakurichi coastal regions are poor organic matter. Least amount of organic matter can cause soil erosion and poor soil texture.

\section{References:-}

1. Nwachokor MA, Uzu FO and Molindo WA, Variations in Physicochemical Properties and Productivity Implications for Four Soils in the Derived Savannah of Southern Nigeria,American-Eurasian Journal of Agronomy, 2009,2 (3), 124-129.

2. Jha AK and Singh JS, Soil characteristics and vegetation development of an age series of mine spoil in a dry tropical environment. Vegetatio ,1991,97, $63-76$.

3. Joffe JS, 1949. Pedology: PedologyPubl., New Brunswick, N. J.

4. Schnitzer M, Binding of humic substances by soil colloids. In: Huang P.M., M. Schnitzer (Eds.), Interactions of soil minerals with natural organics and microbes, 1986,pp. 77E 1. Special Publication No.17, Soil Science Society of America, Madison, WI.

5. Paudel S and Sah JP, Physiochemical characteristics of soil in tropical sal (Shorea robusta Gaertn.) forests in eastern Nepal. Himalayan J. Sci. 2003, 1(2),107-110.

6. C. Johny, S. Jeeva, N.C.J. Packia Lekshmi, J. Raja Brindha, G. Blessy and S. Mary Josephine Punitha(2016)Int. J. Pure App. Biosci. 4 (5): 182-190

7. Akpoveta OV,Osakwe SA, Okoh BE, Otuya BO, Physicochemical Characteristics and Levels of Some Heavy Metals in Soils around Metal Scrap Dumps in Some Parts of Delta State, Nigeria, J. Appl. Sci. Environ. Manage, 2010, 14 (4), 57 - 60.

8. Brady C N, Weil RR,Nature and properties of soils, 2002,13th Ed. Prentice Hall.

9. Adhikari K, Guadagnini A, Toth $\mathrm{G}$ and Hermann T, Geostatistical analysis of surface soil texture from Zala county in western Hungary, International Symposium on Environment, Energy and Water in Nepal: Recent Researches and Direction for Future, 2009.

10. Shirbhate N and Malode SN, Municipal Solid WasteManagement: A Survey And Physicochemical Analysis Of Contaminated Soil From Sukali Compost And Landfill Depot, Batkuli Road, Amravati.G.J.B.B., 2012,1 (2) , 215-219.

11. Wagh GS, Chavhan DM and Sayyed MRG, Physicochemical Analysis of Soils from Eastern Part of Pune City.Uni.J.of Env.Res.and Tech., 2013,3(1),93-99.

12. Singh DP and Rathore MS,Available nutrient status and their relationship with soil properties of Aravalli mountain ranges and Malwa Plateau of Pratapgarh, Rajsthan, India.African J. of Agric.Res. 2013,8(41),50965103.

13. Patil SL, Sheelavantar MN, Nalatwadmath SK, Surkod VS,Mana Mohan S and Lamani VK, Correlation Analysis Among Soil Moisture, Soil Physico-Chemical Propertise, Nutrient Uptake And Yield Of Winter Sorghum.Ind.J.Agric.Res. 2005,39(3),177-185.

14. Miller RW and Donahuer RL, Soils in our environment, 2001, Seventh edition. Prentice Hall, Inc. Upper Saddle River, New Jersey. 
15. Sumithra S, Ankalaiah C, Rao D and Yamuna RT, A case study on physico - chemical characteristics of soil around industrial and agricultural area of yerraguntla, kadapa district, A. P, india. Int. J. Geo. Earth and Environ. Sci. 2013,3(2), 28-34.

16. Campbell RE and Rouss JO, TerracingEconomics of Iowa Soils, J. Soil and Water Cons. 1961, 41(1), 49-52.

17. Hodes SC, Soil fertility basics: N.C. certified crop advisor training, Soil Science Extension, North Carolina State University, 1996, 75. Chemical Science Review and Letters ISSN 2278-6783 Chem Sci Rev Lett 2015, 4(13), 57 - 66 Article CS29204512 64

18. Russell EJ, Soil conditions and plant growth,1950,Biotech Books, New Delhi, India.

19. Ramulu SUS, Reuse of municipal sewage and sludge in agriculture,2001, Scientific publishers Jodhpur, India 86. 